\title{
The Association Between Chiropractic Conservatism and the Ability to make Appropriate Clinical decisions: A Survey on Chiropractic Students in Denmark
}

Casper Glissmann Nim ( $\nabla$ casper.nim@rsyd.dk)

Syddansk Universitet https://orcid.org/0000-0001-5845-2622

\section{Søren O'Neill}

University Hospital of Southern Denmark

\section{Henrik Hein Lauridsen}

University of Southern Denmark

\section{Guillaume Goncalves}

Institut Franco Européen de Chiropraxie

\section{Rikke Krüger Jensen}

University of Southern Denmark

Charlotte Leboeuf-Yde

University of Southern Denmark

\section{Research}

Keywords: Chiropractic students, Chiropractic Conservatism, Spinal subluxation, Spinal adjustments, Contraindication, Non-indication, Indication, Education, Survey

Posted Date: April 13th, 2020

DOI: https://doi.org/10.21203/rs.3.rs-22023/v1

License: (9) This work is licensed under a Creative Commons Attribution 4.0 International License. Read Full License 


\section{Abstract}

Background We investigated whether a university-based educational system would overrule the strong link (odds ratios $>20$ ) between chiropractic conservatism and the inability to recognize non-indications to chiropractic treatment that had been shown to exist in a previous study of a private chiropractic college. We i) sought to define the clinical decision profile of the students in a university-based course embedded in a medical school, and ii) investigated whether students' clinical judgment was affected by their conservatism score determined from a ten item questionnaire and collapsed into four categories.

Methods In a cross-sectional survey, 3 rd to 5 th year chiropractic students, attending the University of Southern Denmark and recently graduated interns were categorized into four levels of conservatism, which were crosstabulated with the ability to answer appropriately on 9 cases concerning i) contra-indications, ii) non-indications and iii) indications to chiropractic treatment. Data were analyzed using logistic regression.

Results In all, 146 participants (76\%) completed the survey, of which 70\% belonged in the two lowest conservatism groups with three outliers (group 4). Their ability to answer correctly to the clinical cases was generally acceptable. The level of conservatism (categories 1-3) was moderately (but not statistically significantly) associated with an inability to recognize non -indications to treatment (odds ratios $~ 3.5$ ). Three outliers (category 4), however, answered inappropriately on the majority of the 9 clinical cases.

Conclusions The Danish students' clinical acumen in correctly judging the appropriateness of spinal manipulation in the clinical cases was fairly similar to that shown in the previous survey on chiropractic students attending a private college. Contrary to the findings at the private college, the level of conservatism did not have a strong association with the inability to recognize non-indications. Although a university-based education does not immunize its students against chiropractic conservatism, it does appear to attenuate its consequences on their clinical judgment.

\section{Introduction}

The chiropractic profession consists of several factions, two of which are vehemently opposed to each other, namely those who claim to be able to treat non-musculoskeletal conditions and those who restrain their practice to the musculoskeletal areas (1). Both groups probably consider themselves 'evidence-based' but the former group has more problems being accepted by main-stream health care professionals and may also practice contrary to the laws of their country (1).

It appears that conservative chiropractors who offer treatment for non-musculoskeletal disorders do so on different theoretical grounds, all rooted in the idea that spinal 'subluxations' are a threat to health which can be ameliorated by spinal 'adjustments'. Some argue that spinal 'adjustments' in accordance with the so-called meric system can have a beneficial effect on the autonomic nervous system, thereby improving the functioning of internal organs (2). Others make reference to outright vitalistic notions of an inner life force called 'innate intelligence' (3). Finally, albeit less common, theories include improving the circulation of cerebrospinal fluid (4) and bringing dormant neurons of the central nervous system back to function, by means of spinal 'adjustments' (5). By the same line of thinking, chiropractic treatment is also purported to boost the immune system, and some chiropractors are even vocal opponents of vaccination programs $(6,7)$. 
The authors of this article identify unambiguously with the musculoskeletal faction and consider nonmusculoskeletal conditions a non-indication for chiropractic treatment, until convincing scientific evidence suggests otherwise. However, it is logical that chiropractors, who believe that spinal 'subluxations' cause disease and that the spinal 'adjustment' is a powerful treatment for many conditions, also accept patients for non-musculoskeletal treatment. Non-indications for us may therefore represent indications for them.

This was confirmed in a survey of chiropractic students at a European private chiropractic college, in which a number of cases were presented asking whether the students would accept to treat a patient with i) contraindications, ii) non- indications, and iii) indications to treatment, and comparing these choices to their degree of chiropractic conservatism, using a ten-item questionnaire (8). Conservatism was assessed as agreement to antiquated chiropractic tenets, such as: "Subluxations are the cause of all disease"; "Adjustments can prevent disease in general"; "Adjustments help the body function at $100 \%$ of its capacity", etc. The answers to ten such questions were quantified as a score between 0 and 10 (from the lowest to the highest conservatism score).

A strong positive association was reported between a firm adherence to the chiropractic conservative belief system and the willingness to treat non-indicated cases. There was also a dose-response relationship between the conservatism score and an inability/unwillingness to accept limitations to the indications to chiropractic treatment. For example, students in the highest category of conservatism, were 20 times more likely than those in the lowest category to offer treatment to children to "prevent diseases from developing in the future".

A subsequent survey showed that at our university-based medical-school-embedded chiropractic institution in Denmark, students had a completely different conservatism profile compared to that of the private college. In fact, an inverse relationship was observed, with $75 \%$ of students from the private college in the two higher conservatism categories (i.e. answered 'inappropriately' on a minimum of six of the ten conservatism items), and $70 \%$ of the university students in the two lower categories (i.e. answered 'inappropriately' on a maximum of 4 items) (9). In all, only three individuals in the university course were found to agree to most of these ten conservatism tenets.

The contrast observed between the two institutions could be explained by differences in the educational setup. The chiropractic program at the University of Southern Denmark is a five-year master program with a bachelor that is approximately $90 \%$ equivalent to the bachelor in the medical school (10), and where the clinical courses are primarily completed at publicly funded regional hospitals, including a longer stay at a secondary sector spine center, as opposed to obtaining clinical training in a strictly primary practice setting, such as in a student clinic outside the hospital system

We were interested to see if such conservative attitudes would overrule the strong educational message provided in this environment. Therefore, we reproduced part of the previous survey to see if our results would indicate the same link between chiropractic conservative views and clinical decision making.

Our specific objectives were i) to define the clinical decision profile of the students in the Danish course reported by year of study, and ii) to investigate if this decision profile is affected by the level of conservatism score after controlling for sex and year of study.

\section{Method}




\section{Settings}

A cross-sectional, anonymous, and voluntary survey was distributed to students attending the chiropractic program at University of Southern Denmark, in their 3rd to 5th academic year, and to recently graduated students who were enrolled in the obligatory 1 -year internship program at either a primary or secondary care practice in Denmark.

Students were informed of the study by email (via the internal university information platform) with two later reminders ( $8^{\text {th }}$ and $22^{\text {nd }}$ of October 2019). Furthermore, information was presented in-class by a lecturer or researcher involved in the study. Students were allowed time to complete the survey during regular class. The first page of the survey consisted of a brief explanation of the project identical to that of the private college study (Supplementary File 1).

Clinical interns were informed about the study during a meeting pre-scheduled as part of the internship program (Oct. $\left.27^{\text {th }}, 2019\right)$. Time was allowed initially in the meeting to complete the survey. No reminders were sent.

It took approximately 10 minutes to complete the survey which was conducted using SurveyXact (11), and all data were collected anonymously online. No attempts were made to identify any of the respondents on the basis of their demographic data or replies. No ethics permission is necessary to conduct an anonymous survey in Denmark (12).

\section{Survey}

The survey instrument consisted of two parts:

\section{Conservatism}

The first part was a chiropractic conservatism questionnaire with six statements regarding chiropractic spinal 'adjustments' and four statements regarding spinal 'subluxations'. These were Danish translations of the previously published questionnaire used in the private college study (4) (Table 1). Responses were collected using 5-point Likert scales anchored with 'Definitely not'/'Strongly disagree' to 'Yes, definitely'/'Strongly agree' (Supplementary file 2).

Table 1. Ten statements used to determine the degree of conservatism 


\begin{tabular}{|c|c|}
\hline Items regarding spinal manipulation/adjustments & Items regarding spinal dysfunctions/subluxations \\
\hline Adjustments can prevent disease in general & Subluxations are the cause of all disease \\
\hline Adjustments can help the immune system & Subluxations cause short-circuits of the nervous system \\
\hline Adjustments can improve the health of infants & $\begin{array}{l}\text { Subluxations can have a negative effect on the capacity of the nervous system to } \\
\text { provide energy to tissues and organs }\end{array}$ \\
\hline Adjustments can help the body function at $100 \%$ of its capacity & It is possible to detect subluxations before symptoms appear \\
\hline Adjustments can prevent degeneration of the spine & \\
\hline $\begin{array}{l}\text { It is appropriate for every person to receive chiropractic } \\
\text { adjustments for their entire life }\end{array}$ & \\
\hline
\end{tabular}

\section{Clinical decision-making}

The survey further included 9 clinical cases concerning I) low back pain $(n=4)$, II) neck pain $(n=3)$, and III) primary prevention in a child $(n=2)$. The full questionnaire is provided in Supplementary File 2.

These three sets of clinical cases were used to assess students' ability to detect contra-indications, nonindications, and indications for spinal manipulation. See Box 1

BOX 1: Definitions of the different indications used in a survey on chiropractic students attending the University of Southern Denmark

Contra-indication: Cases where spinal manipulation would be associated with a non-trivial risk of complications e.g. manipulation of spinal fracture.

Non-indication: Cases where spinal manipulation is not contra-indicated, but where no evidence-based clinical rationale for offering the treatment is present e.g. manipulation offered as treatment of asthma or as prevention for infection.

Indication: Cases where spinal manipulation is not contra-indicated, and musculoskeletal symptoms are present with clinical findings providing an evidence-based rationale for spinal manipulation e.g. spinal pain syndrome with biomechanical dysfunction.

\section{Translation process and pilot testing}

The survey was translated using a modified cross-cultural adaptation technique (13). A fluent English and Danish speaker (SON) translated the original English version to Danish, and afterwards another fluent English and Danish speaker (HHL) translated it back to English. Finally, a consensus meeting between SON, HHL and CGN was held, and the final Danish version was agreed upon. The survey was pilot tested by four chiropractors who recently completed their internship. This did not generate any changes to the survey.

\section{I) Low back pain questionnaire}


A subset of four questions were adopted from a previously published and validated questionnaire (14-16) related to a case of a 40-year old male with local LBP and no additional musculoskeletal complaints.

In the four questions, the case develops in four different ways: i) no prior LBP and complete remission after two sessions, ii) previous recurrent LBP and complete remission after two weeks, iii) previously one year of intermittent LBP and gradual worsening over six sessions, iv) previously one year of intermittent LBP, minor (clinically irrelevant) improvement after six sessions and possible undiagnosed underlying depression.

The respondents were asked to choose one of seven possible strategies for each of the four case-developments a) second opinion, b) additional treatment, c) 'quick-fix', d) try again, e) symptom guided maintenance care (patient administered), f) clinical guided maintenance care (clinician administered), and g) finally, students could reply other and add an answer in the comment section. Cases iii) and iv) were considered to be nonindicated for continued care because iii) was a case where the patient does not respond to spinal manipulation but gradually worsens and iv) indicates a non-mechanical LBP pattern most likely due to a non-musculoskeletal condition (depression).

\section{II) Neck pain questionnaire}

A subset of three questions were adopted from a questionnaire previously used in a study of French chiropractors (17). The case describes a 28-year old male tennis player with neck pain and antalgic head position. The case develops in the following three ways: i) Simple mechanical, local neck pain, ii) simple mechanical neck pain with radiation to the trapezius muscle, and iii) development of signs of an upper motor lesion. The first two cases were considered indications to treatment, whereas the third was an obvious contraindication.

\section{III) Primary prevention in a child}

We included two additional questions adopted from the previous study of the private college (8) regarding primary prevention. The first case concerns the mother of a 5-year old child with no prior spinal pain, who consults a chiropractor, asking if the chiropractor would be able to treat the child preventively to avoid future spinal pain. The second case describes the mother of a 5-year old child with a long family history of multiple comorbidity, breast cancer, diabetes etc., who asks if the chiropractor would be able to treat the child preventively to avoid the onset of diseases in the future. Both cases were obvious non-indications to chiropractic treatment.

\section{Interpretation of "other"}

For the clinical cases, the students also had the possibility to answer other and write a comment. All comments were read thoroughly and independently by two authors (CGN and SON). When consensus could be reached the 'other' answers were re-classified into one of the fixed answer possibilities or left under 'other'. If consensus could not be achieved, a third author $(\mathrm{HHL})$ arbitrated the decision.

\section{Variables of interest}


Answers to the nine clinical cases were dichotomized into an 'appropriate' answer (0) and an 'inappropriate' answer (1) as defined in the primary publication (18). The rationale for these is described in Supplementary File 3.

\section{Independent variable (chiropractic conservatism)}

Each answer to the 10 questions concerning chiropractic conservatism was dichotomized into an 'appropriate' answer [0] and an 'inappropriate' answer [1], using the same classification as that used in the previous study on this topic (8). A total sum of inappropriate answers was calculated and used as 'the conservatism score' [0-10]. This score was then further categorized into four groups: group 1 with scores of 0-2, group 2 including scores of $3-5$, group 3 for scores of 6-7, and group 4 included scores of 8-10, i.e. the same categorization as previously reported (8).

In addition, sex, age, and academic year were included as descriptive variables.

\section{Statistics}

Descriptive data for age is reported as the mean and standard deviation. All categorical data are reported as count, frequency and binary 95\% confidence intervals. The proportion of 'appropriate' answers to the clinical questions is visualized as bar graphs for each question per academic year, including error bars representing $95 \%$ confidence interval.

The associations between the dependent variables (clinical appropriateness) and the independent variable (the conservatism score) were tested for statistical significance using logistic binomial regression, both unadjusted and adjusted for sex and academic year. All associations are presented as odds-ratios with $95 \%$ confidence intervals. Non-overlapping of confidence intervals would determine if differences are statistically significant.

Data analyses and data wrangling of the Danish study were performed using the tidyverse (19) in R (20) (Linux, v. 3.6.0 with R-studio v. 1.1.456). The exactci package (21)was used to calculate $95 \%$ confidence intervals (CI).

\section{Results}

\section{Descriptive data}

A total of 191 students were invited to participate, and 146 (76\%) completed the survey, of which 80 (55\%) were female. The mean age was $25.7(S D=2.9)$ years.

Information on academic year, sex and conservatism group is presented in Table 2.

Three students were considered outliers, the only ones to be placed in the highest conservatism group. They were excluded from the group analysis, to be reported on separately and in detail later in the results section.

Table 2. A descriptive presentation of 146 chiropractic students at the University of Southern Denmark and one-year interns. 


\begin{tabular}{|l|l|l|l|}
\hline & Total & Males & Females \\
& N (\% of respondents of all students per year of study) & N \% of responders) & N (\% of responders) \\
\hline Academic year of study & & & \\
\hline Interns & $24(100)$ & $10(100)$ & $14(100)$ \\
\hline $5^{\text {th }}$ year & $48(89)$ & $19(79)$ & $29(97)$ \\
\hline $4^{\text {th }}$ year & $35(74)$ & $15(75)$ & $20(74)$ \\
\hline $3^{\text {rd }}$ year & $36(59)$ & $19(61)$ & $17(57)$ \\
\hline Missing & 3 & & \\
\hline Conservatism group & & & \\
\hline Gissing & N (\%) [95\% CI] & & \\
\hline Group 1 & $66(45)[37-54]$ & & \\
\hline Group 2 & $52(36)[28-44]$ & & \\
\hline Group 3 & $17(12)[7-18]$ & & \\
\hline Group 4 & $(2-11]$ & & \\
\hline
\end{tabular}

\section{Interpretation of "other"}

Seventy-two answers were provided in the 'other' category with written comments. After carefully reviewing these, 24 were re-categorized as the comment was encompassed by one of the provided 'fixed' answer options. In total, $2.1 \%$ of all answers were re-categorized from 'other' i.e. 'inappropriate ' to 'appropriate' e.g. an appropriate clinical rationale.

\section{Ability to determine contra-indications}

Participants' ability to recognize contra-indications, grouped by year of study is presented in Figure 1. For the first clinical case (patient with an upper motor lesion), the majority of students, across classes, correctly recognized the need for referral (between 83 and 92\%). By contrast, for the clinical case with the patient who gradually got worse with treatment, only between 25 and $42 \%$ would refer this patient on for a second opinion. However, for the second case, the confidence intervals are wide. 


\section{Ability to determine non-indications}

The ability to identify non-indications is depicted in Figure 2. Similarly, to the case with the pain aggravation, only between $33-63 \%$ would refer a depressive patient for a second opinion, with no significant differences between the years of study, again with wide confidence intervals. For the remaining cases, the participants answered 'appropriately' in 71 to $100 \%$ of the instances.

The case concerning an asymptomatic patient, between $77 \%$ ( $3^{\text {rd }}$ year students) and $96 \%$ (postgraduate interns) would consider the treatment as completed. Between 71 and $100 \%$ would not offer treatment as prevention of spinal pain syndromes or disease in general, for children.

Overall, the appropriate answers appears to improve as the year of study increases.

\section{Ability to determine indications}

Figure 3 shows the participants' ability to identify 'appropriate' chiropractic clinical indications. In general, the participants found it difficult to identify indications for treatment in the following situations: i) a case describing simple mechanical neck pain, where between 68 and $88 \%$ would treat this on their own, ii) when the pain radiates to the shoulder, the frequency drops to between 33 and $81 \%$ with large differences observed for the $3^{\text {rd }}$ and $5^{\text {th }}$ years vs. $4^{\text {th }}$ year and interns, and iii) a potential maintenance care patient would be correctly given a maintenance care treatment plan by 51 to $73 \%$ of participants.

To conclude, participants were most likely to treat simple, local neck pain on their own, less able at identifying a maintenance care patient and less interested in providing treatment on their own for simple neck pain with pain radiating to the shoulder, with some between-class estimate differences.

\section{Associations between students' conservative score and their ability to make 'appropriate' clinical decisions.}

It was not possible to perform the logistic regression for the conservatism groups using the four scores, as only three students were identified as highly conservative (group 4). Thus, these students were omitted from the initial analysis and described individually. The unadjusted and adjusted (sex and year of study) analyses for all other participants are presented in Tables 3 and 4. Both the unadjusted and the adjusted associations between conservatism group and inability to determine non-indications, showed that the most conservative group (i.e. group 3) found this most difficult. However, none of the differences between group 1 and 3 were statistically significant.

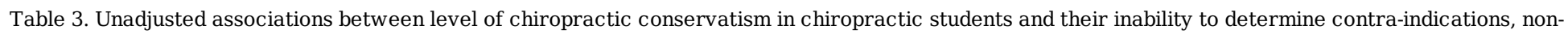
indications, or indications to chiropractic treatment 


\begin{tabular}{|c|c|c|c|c|c|c|c|c|c|}
\hline \multirow[b]{2}{*}{$\begin{array}{l}\text { Conservatism } \\
\text { group }\end{array}$} & \multicolumn{2}{|c|}{ Contra-indications } & \multicolumn{4}{|c|}{ Non-indications } & \multicolumn{3}{|l|}{ Indications } \\
\hline & $\begin{array}{l}\text { CP3, } \\
\text { OR[95\%CI] }\end{array}$ & $\begin{array}{l}\text { LBP3, } \\
\text { OR[95\%CI] }\end{array}$ & $\begin{array}{l}\text { LBP4, } \\
\text { OR[95\%CI] }\end{array}$ & $\begin{array}{l}\text { LBP1, } \\
\text { OR[95\%CI] }\end{array}$ & $\begin{array}{l}\text { PED1, } \\
\text { OR[95\%CI] }\end{array}$ & $\begin{array}{l}\text { PED2, } \\
\text { OR[95\%CI] }\end{array}$ & $\begin{array}{l}\text { CP1, } \\
\text { OR[95\%CI] }\end{array}$ & $\begin{array}{l}\text { CP2, } \\
\text { OR[95\%CI] }\end{array}$ & $\begin{array}{l}\text { LBP2, } \\
\text { OR[95\%CI] }\end{array}$ \\
\hline 1 (index) & 1 & 1 & 1 & 1 & 1 & 1 & 1 & 1 & 1 \\
\hline 2 & $\begin{array}{l}2.18(0.68 \text { - } \\
7.65)\end{array}$ & $\begin{array}{l}2.11(0.95- \\
4.83)\end{array}$ & $\begin{array}{l}1.26(0.6- \\
2.67)\end{array}$ & $\begin{array}{l}2.16(0.67 \text { - } \\
7.57)\end{array}$ & $\begin{array}{l}1.53(0.51- \\
4.68)\end{array}$ & $\begin{array}{l}\text { Too few } \\
\text { cases }\end{array}$ & $\begin{array}{l}1.07(0.44- \\
2.58)\end{array}$ & $\begin{array}{l}1.58(0.76- \\
3.32)\end{array}$ & $\begin{array}{l}0.46(0.21- \\
0.99)\end{array}$ \\
\hline 3 & $\begin{array}{l}1.6(0.21- \\
8.26)\end{array}$ & $\begin{array}{l}1.59(0.51- \\
5.55)\end{array}$ & $\begin{array}{l}1.72(0.57- \\
5.62)\end{array}$ & $\begin{array}{l}3.87(0.85- \\
16.83)\end{array}$ & $\begin{array}{l}3.51(0.91- \\
12.99)\end{array}$ & $\begin{array}{l}\text { Too few } \\
\text { cases }\end{array}$ & $\begin{array}{l}0.48(0.07- \\
1.97)\end{array}$ & $\begin{array}{l}1.02(0.33- \\
3.01)\end{array}$ & $\begin{array}{l}0.50(0.14- \\
1.55)\end{array}$ \\
\hline
\end{tabular}

CP3 = Cervical pain and signs of upper motor lesion. LBP3 = Low back pain aggravation after treatment. LBP4 = Low back pain with underlying depression. LBP1 = Mechanical Low back pain. PED1 = Primary prevention of back disorders. PED2 = Primary prevention of diseases. CP1 $=$ Mechanical neck pain. $\mathrm{CP} 2=$ Mechanical neck pain with radiation to the trapezius. LBP2 $=$ Recurrent low back pain

Table 4. Adjusted associations between level of chiropractic conservatism in chiropractic students and their inability to determine contra-indications, nonindications, or indications to chiropractic treatment

\begin{tabular}{|l|l|l|l|l|l|l|l|l|l|}
\hline & \multicolumn{2}{l|}{ Contra-indications } & \multicolumn{2}{l|}{ Non-indications } & \multicolumn{2}{l|}{ Indications } \\
\hline $\begin{array}{l}\text { Conservatism } \\
\text { group }\end{array}$ & $\begin{array}{l}\text { CP3, } \\
\text { OR[95\%CI] }\end{array}$ & $\begin{array}{l}\text { LBP3, } \\
\text { OR[95\%CI] }\end{array}$ & $\begin{array}{l}\text { LBP4, } \\
\text { OR[95\%CI] }\end{array}$ & $\begin{array}{l}\text { LBP1, } \\
\text { OR[95\%CI] }\end{array}$ & $\begin{array}{l}\text { PED1, } \\
\text { OR[95\%CI] }\end{array}$ & $\begin{array}{l}\text { PED2, } \\
\text { OR[95\%CI] }\end{array}$ & $\begin{array}{l}\text { CP1, } \\
\text { OR[95\%CI] }\end{array}$ & $\begin{array}{l}\text { CP2, } \\
\text { OR[95\%CI] }\end{array}$ & $\begin{array}{l}\text { LBP2, } \\
\text { OR[95\%CI] }\end{array}$ \\
\hline 1 (index) & 1 & 1 & 1 & 1 & 1 & 1 & 1 & 1 \\
\hline 2 & $\begin{array}{l}2.33(0.63- \\
9.15)\end{array}$ & $\begin{array}{l}1.79(0.75- \\
4.41)\end{array}$ & $\begin{array}{l}1.52(0.67- \\
3.56)\end{array}$ & $\begin{array}{l}2.82(0.81- \\
10.83)\end{array}$ & $\begin{array}{l}1.77(0.5- \\
6.66)\end{array}$ & $\begin{array}{l}\text { Too few } \\
\text { cases }\end{array}$ & $\begin{array}{l}1.51(0.55- \\
4.2)\end{array}$ & $\begin{array}{l}1.94(0.8- \\
4.91)\end{array}$ & $\begin{array}{l}0.58(0.25- \\
1.34)\end{array}$ \\
\hline 3 & $\begin{array}{l}2.25(0.27- \\
14.44)\end{array}$ & $\begin{array}{l}1.23(0.36- \\
4.67)\end{array}$ & $\begin{array}{l}2.05(0.61- \\
7.44)\end{array}$ & $\begin{array}{l}4.83(0.93- \\
25.18)\end{array}$ & $\begin{array}{l}2.66(0.57- \\
12.86)\end{array}$ & $\begin{array}{l}\text { Too few } \\
\text { cases }\end{array}$ & $\begin{array}{l}0.83(0.11- \\
4.07)\end{array}$ & $\begin{array}{l}1.14(0.3- \\
4.23)\end{array}$ \\
\hline
\end{tabular}

CP3 = Cervical pain and signs of upper motor lesion. LBP3 = Low back pain aggravation after treatment. LBP4 = Low back pain with underlying depression. LBP1 = Mechanical Low back pain. PED1 = Primary prevention of back disorders. PED2 = Primary prevention of diseases. CP1 = Mechanical neck pain. $\mathrm{CP} 2=$ Mechanical neck pain with radiation to the trapezius. LBP2 $=$ Recurrent low back pain

In general, there was a tendency that $5^{\text {th }}$ year and interns answered more clinically 'appropriately', but this was not statistically significant. Sex had no impact on the outcome of the regression analyses.

\section{Outliers}

Three students were identified as belonging to the most conservative group (group 4). All were females with a conservatism score of 8 or 9 out of 10. As one student stopped answering after the cervical cases, the answers regarding the LBP case are missing. In general, these three students appeared to have difficulty in choosing when to apply maintenance care and when to refer non-indications out. However, the bigger concern was that two did not identify the neck pain case with an upper motor lesion as unsuitable for treatment. Student number three would treat for primary prevention of both spinal pain and general diseases, which was abnormal behavior compared to the rest of the cohort. For a detailed description of each student see Table 5. 


\begin{tabular}{|c|c|c|c|c|c|c|c|c|c|c|}
\hline$\frac{\text { dents }}{\text { roup }}$ & Demographics & $\begin{array}{l}\text { CP1 - } \\
\text { Mechanical } \\
\text { neck pain }\end{array}$ & $\begin{array}{l}\text { MP2 - } \\
\text { Mechanical } \\
\text { neck pain } \\
\text { with } \\
\underline{\text { radiation }}\end{array}$ & $\begin{array}{l}\text { CP3 - } \\
\text { Upper } \\
\underline{\text { motor }} \\
\underline{\text { lesion }}\end{array}$ & $\begin{array}{l}\text { PED1 - } \\
\text { Primary } \\
\text { prevention } \\
\text { of back } \\
\text { disorders }\end{array}$ & $\begin{array}{l}\text { PED2 - } \\
\text { Primary } \\
\text { prevention } \\
\text { of } \\
\text { diseases }\end{array}$ & $\begin{array}{l}\text { LBP1 - } \\
\text { Mechanical } \\
\underline{\text { back pain }}\end{array}$ & $\begin{array}{l}\frac{\text { LBP2 - }}{\text { Recurrent low }} \\
\underline{\text { back pain }}\end{array}$ & $\frac{\text { LBP3 - Pain }}{\text { agggravation }}$ & $\begin{array}{l}\text { LBP4 - } \\
\text { Depression }\end{array}$ \\
\hline & $\begin{array}{l}\text { Female } \\
3^{\text {rd }} \text { year } \\
\text { conservatism } \\
\text { score of } 8\end{array}$ & $\begin{array}{l}\text { I would } \\
\text { treat the } \\
\text { patient } \\
\text { with the } \\
\text { assistance } \\
\text { of another } \\
\text { paramedic }\end{array}$ & \begin{tabular}{|l|} 
I would \\
treat the \\
patient \\
whilst \\
asking the \\
opinion of a \\
specialist
\end{tabular} & $\begin{array}{l}\text { I would not } \\
\text { treat the } \\
\text { patient but } \\
\text { refer him } \\
\text { out }\end{array}$ & $\begin{array}{l}\text { Don't } \\
\text { know }\end{array}$ & $\begin{array}{l}\text { Probably } \\
\text { not }\end{array}$ & No reply & No reply & No reply & No reply \\
\hline & $\begin{array}{l}\text { Female } \\
4^{\text {th }} \text { year } \\
\text { conservatism } \\
\text { score of } 8\end{array}$ & $\begin{array}{l}\text { I would } \\
\text { treat the } \\
\text { patient on } \\
\text { my own }\end{array}$ & $\begin{array}{l}\text { I would } \\
\text { treat the } \\
\text { patient on } \\
\text { my own }\end{array}$ & $\begin{array}{l}\text { I would } \\
\text { treat the } \\
\text { patient with } \\
\text { the } \\
\text { assistance } \\
\text { of a general } \\
\text { practitioner }\end{array}$ & $\begin{array}{l}\text { Probably } \\
\text { not }\end{array}$ & $\begin{array}{l}\text { Don't } \\
\text { know }\end{array}$ & $\begin{array}{l}\text { I would try a } \\
\text { few more } \\
\text { treatments and } \\
\text { perhaps change } \\
\text { my treatment } \\
\text { strategy, until I } \\
\text { am sure that I } \\
\text { cannot do any } \\
\text { more. }\end{array}$ & $\begin{array}{l}\text { I would follow } \\
\text { this patient for a } \\
\text { while, } \\
\text { attempting to } \\
\text { prolong the time } \\
\text { period between } \\
\text { visits until either } \\
\text { the patient is } \\
\text { asymptomatic or } \\
\text { until we have } \\
\text { found a suitable } \\
\text { time lapse } \\
\text { between check- } \\
\text { ups to keep the } \\
\text { patient } \\
\text { symptom-free. }\end{array}$ & $\begin{array}{l}\text { I would try } \\
\text { a few more } \\
\text { treatments } \\
\text { and } \\
\text { perhaps } \\
\text { change my } \\
\text { treatment } \\
\text { strategy, } \\
\text { until I am } \\
\text { sure that I } \\
\text { cannot do } \\
\text { any more. }\end{array}$ & $\begin{array}{l}\text { I would } \\
\text { follow this } \\
\text { patient for a } \\
\text { while, } \\
\text { attempting to } \\
\text { prolong the } \\
\text { time period } \\
\text { between } \\
\text { visits until } \\
\text { either the } \\
\text { patient is } \\
\text { asymptomatic } \\
\text { or until we } \\
\text { have found a } \\
\text { suitable time } \\
\text { lapse } \\
\text { between } \\
\text { check-ups to } \\
\text { keep the } \\
\text { patient } \\
\text { symptom- } \\
\text { free. }\end{array}$ \\
\hline & $\begin{array}{l}\text { Female } \\
3^{\text {rd }} \text { year } \\
\text { conservatism } \\
\text { score of } 9\end{array}$ & $\begin{array}{l}\text { I would } \\
\text { treat the } \\
\text { patient on } \\
\text { my own }\end{array}$ & $\begin{array}{l}\text { I would } \\
\text { treat the } \\
\text { patient } \\
\text { with the } \\
\text { assistance } \\
\text { of another } \\
\text { paramedic }\end{array}$ & $\begin{array}{l}\text { I would } \\
\text { treat the } \\
\text { patient with } \\
\text { the } \\
\text { assistance } \\
\text { of a general } \\
\text { practitioner }\end{array}$ & $\begin{array}{l}\text { Probably } \\
\text { yes }\end{array}$ & $\begin{array}{l}\text { Probably } \\
\text { yes }\end{array}$ & $\begin{array}{l}\text { I would follow } \\
\text { this patient for } \\
\text { a while, } \\
\text { attempting to } \\
\text { prolong the time } \\
\text { period between } \\
\text { visits until } \\
\text { either the } \\
\text { patient is } \\
\text { asymptomatic } \\
\text { or until we have } \\
\text { found a suitable } \\
\text { time lapse } \\
\text { between check- } \\
\text { ups to keep the } \\
\text { patient } \\
\text { symptom-free. }\end{array}$ & $\begin{array}{l}\text { I would advise } \\
\text { the patient to } \\
\text { seek additional } \\
\text { treatment whilst } \\
\text { following the } \\
\text { patient. }\end{array}$ & $\begin{array}{l}\text { I would try } \\
\text { a few more } \\
\text { treatments } \\
\text { and } \\
\text { perhaps } \\
\text { change my } \\
\text { treatment } \\
\text { strategy, } \\
\text { until I am } \\
\text { sure that I } \\
\text { cannot do } \\
\text { any more. }\end{array}$ & $\begin{array}{l}\text { I would refer } \\
\text { the patient to } \\
\text { another } \\
\text { health care } \\
\text { practitioner } \\
\text { for a second } \\
\text { opinion. }\end{array}$ \\
\hline
\end{tabular}

\section{Discussion}

\section{Short summary of the results and comparison with a previous study}


The chiropractic students at the Danish chiropractic course, who participated in this survey, were generally able to identify non-indications to chiropractic treatment, with the exception of some who did not choose to refer a patient on, with only minor improvement and a possible underlying depression. They were also good at identifying an upper motor lesion case as unsuitable for treatment but less able to suggest that a patient who gradually gets worse should be referred out and considered a potential contra-indication for treatment. They would treat a simple mechanical neck pain case on their own but were more reluctant to do so when the pain radiated towards the shoulder.

Sex and year of study.

In the present study, no statistically significant changes appeared when controlling for sex and year of study, although the estimates in general were better for the fifth-year students and interns.

Similarities and differences with previous study on effect of conservatism

The students' clinical choices were similar to those reported in the previous study from the private chiropractic college (4). Interestingly, discrepancies between the conservative groups related mainly to the non-indicated cases, both in the present and the previous study. However, in the Danish university student cohort, these results never reached statistical significance, whereas in the private school, explicit associations were observed with exceptionally strong associations between a high level of conservatism and an inability to recognize nonindications. More specifically, this related to the cases concerning primary prevention of spinal disorders and general diseases in children, and the case about treating an asymptomatic patient. In other words, the Danish students' level of conservatism had lesser impact on their clinical acumen. This difference was so remarkable that it has been illustrated in Table 6, for easy comparison. Furthermore, in Denmark while academic year of study appears to improve clinical acumen, in the private college sixth-year students were least likely to recognize non-indications (4).

By contrast to the study on the private college, the highly conservative group four in the current data constituted only three individuals and were therefore treated as outliers. On the face of it, their replies should raise cause for concern, as patient safety was jeopardized in at least two of the answers they gave. Disturbingly, this conservative reasoning is in adherence with the original chiropractic philosophy (14). Other possibilities are that they did not understand the question or had a different interpretation of the answers.

Apart from important possible 'philosophical' difference, the students from the private college and the university-based course, agreed about the majority of the remaining clinical cases. The students from the private college did, however, answer more appropriately for the cases concerning i) pain aggravation and ii) maintenance care. 


\begin{tabular}{l|l|l|l|l|l|l|l|l|}
\hline \multicolumn{7}{l|}{ Chiropractic students from the university in Denmark } & \multicolumn{4}{l}{ Chiropractic students from the European private college } \\
\hline group & PED1, OR & PED2, OR & LBP1, OR & LBP4, OR & PED1, OR & PED2, OR & LBP1, OR & LBP4, OR \\
\hline & 1 & 1 & 1 & 1 & 1 & 1 & 1 & 1 \\
\hline & 1.53 & Too few cases & 2.16 & 1.26 & 3.4 & 3.4 & 1.7 & 0.7 \\
\hline & 3.51 & Too few cases & 3.87 & 1.72 & 8 & 7.9 & 2.5 & 0.6 \\
\hline & Too few cases & Too few cases- & Too few cases- & -Too few cases & 13.8 & 20.4 & 4.3 & 0.7 \\
\hline
\end{tabular}

\section{Implications of the results}

Despite the strong academic foundation in the Danish chiropractic program, a surprisingly high number of misconceptions surrounding spinal manipulation was evident in our data. This impacted a tendency towards students missing or ignoring non-indications. When this can be observed, in what would arguably be the 'flagship' for a modern chiropractic program, it should not be surprising that conservative chiropractic ideas are also influencing young students at a non-university based educational institution (8).

The association between conservatism and the ability to make appropriate clinical judgments did not reach statistical significance, possibly due to the low number of highly conservative students. In any case, our estimates suggest that the impact of conservatism on critical clinical judgments (contra-indications) was limited.

It is well-known, that a limited faction of chiropractic clinicians still adhere to conservative ideas from the 19th century, but recent studies including this one, indicates that such ideas are not limited to clinical practice but also can be found among pre-graduate students $(8,18)$. Albeit at a low prevalence, conservative chiropractic ideas can even be found in modern, university-based chiropractic courses (9).

To verify these results a follow-up qualitative analysis ought to be conducted. This would clarify i) how the students understand the clinical cases and more importantly the different answering possibilities.

\section{Elimination of conservatism at the Danish institution}

A teaching institution thus appears to be able to impact the prevalence of conservative ideas in the student population (9). In the case of the Danish course, both the course management and student organization are signatories of the International Clinical and Professional Chiropractic Education Position Statement (22).

Further, in the curriculum of the Danish university course, conservative chiropractic ideas and concepts like the spinal 'subluxation' are taught exclusively as objects of historical relevance. Consequently, the teaching institution is not the only factor which determines whether conservative dogma takes root in a student population. 
Nevertheless, it appears necessary that, the course work given on the indications for spinal manipulation, in particular, has to be extended from simple contra-indications to include lectures on when it should be applied and more importantly when it should not be applied.

\section{Methodological Considerations}

We consider the survey to have had an acceptable response rate to adequately represent the student cohort. However, as the participants were anonymous, responders and non-responders cannot be compared, so this remains an assumption.

The clinical cases in the questionnaire had already been administered in two other student settings $(8,18)$, was translated to Danish in an appropriate fashion, and piloted before use. However, some uncertainty may have arisen due to the lack of clinically oriented detail.

As with the questions concerning the conservatism score, which is the basis both for this study and the study conducted at the private college, some of the cases used could suffer from poor content validity (23) despite having gone through a pilot test $(8,9)$. Thus, the clinical interpretation could be misguided.

We have interpreted our results as if students' clinical acumen develops during their study period. It is, of course, also possible that the differences observed between years of study solely reflect peculiarities for each specific cohort. To obtain clarity on this question, longitudinal studies would have to be performed.

Another potential limitation is that we only compared the results to another chiropractic school and not with a similar heath care profession. Perhaps a fraction of medical students also believes in 19th century medical concepts such as, smoking is good for you and 'miasmas' are the cause of cholera; theories that became obsolete around the same time as chiropractic conservatism emerged $(3,24,25)$.

\section{Conclusion}

Chiropractic students in a university-based chiropractic program, embedded in a medical faculty, and chiropractic students at a private non-university based college were quite good and rather similar in their attitudes to which patients to accept (indications) and not to accept (contra-indications) for treatment. Both groups were less at ease with selecting the non-indicated cases.

Students' 'philosophical' approach to some old chiropractic tenets relating to spinal 'subluxations' and spinal 'adjustments' affected these attitudes very strongly at the private college. For this student cohort the data went in the same direction, but not significantly.

The sources of such concepts need to be identified and eradicated, if chiropractors in Denmark will be certain to maintain their privileged status in the health care system.

\section{Abbreviations}

$\mathrm{Cl}$

Confidence interval 


\section{Declarations}

\section{Ethics approval and consent to participate}

Not applicable as no ethical permission is necessary to conduct an anonymous survey in Denmark.

\section{Consent for publication}

Not applicable.

\section{Availability of data and materials}

The data are available from the corresponding author upon request.

\section{Competing interests}

$\mathrm{HHL}$, SON and RKJ are all lectures at the Biomechanics course at the University of Southern Denmark and HHL is the head of the Chiropractic program but had no influence on the data analysis or interpretation. CLY is a senior editorial adviser to the journal Chiropractic \& Manual Therapies but was not a part of the post submission progress.

\section{Funding}

No external funding was provided.

\section{Authors' contributions}

- CGN, GG, SON and CLY: Designed the study.

- CGN, SON, and HHL: Completed the translation and validation of the questionnaire.

- CGN, SON, HHL: Organized and conducted the questionnaire sessions.

- CGN: Completed the analysis and interpreted the results.

- CGN and CLY: Wrote the initial draft

- HHL and RKJ: Provided valuable insight into the chiropractic program at the University of Southern Denmark

- All authors contributed to the interpretations of the results and agreed upon the final manuscript.

\section{Acknowledgments}

$\mathrm{HHL}$, SON and RKJ are all lecturers at the Biomechanics course at the University of Southern Denmark and HHL is the head of the Chiropractic program, but did not have impact on the analyses or statistical outcomes. CLY is a senior editorial adviser to the journal Chiropractic \& Manual Therapies but was not a part of the post submission progress.

\section{References}


1. Leboeuf-Yde C, Innes SI, Young KJ, Kawchuk GN, Hartvigsen J. Chiropractic, one big unhappy family: better together or apart? Chiropractic \& Manual Therapies [Internet]. 2019 Dec [cited 2019 Aug 7];27(1). Available from: https://chiromt.biomedcentral.com/articles/10.1186/s12998-018-0221-z

2. Hynes RJR, Callender AK. Technique in the Classroom at Palmer College of Chiropractic: A History in the Art of Chiropractic. Journal of Chiropractic Humanities. 2008 Jan;15:55-66.

3. Vernon H. Historical overview and update on subluxation theories. Journal of Chiropractic Humanities. 2010 Dec;17(1):22-32.

4. Leboeuf $\mathrm{C}$. The reliability of specific sacro-occipital technique diagnostic tests. J Manipulative Physiol Ther. $1991 \mathrm{Dec} ; 14(9): 512-7$.

5. Meyer A-L, Amorim M-A, Schubert M, Schweinhardt P, Leboeuf-Yde C. Unravelling functional neurology: does spinal manipulation have an effect on the brain? - a systematic literature review. Chiropractic \& Manual Therapies [Internet]. 2019 Dec [cited 2019 Nov 4];27(1). Available from: https://chiromt.biomedcentral.com/articles/10.1186/s12998-019-0265-8

6. Gleberzon B, Lameris M, Schmidt C, Ogrady J. On Vaccination \& Chiropractic: when ideology, history, perception, politics and jurisprudence collide. J Can Chiropr Assoc. 2013 Sep;57(3):205-13.

7. Colley F, Haas M. Attitudes on immunization: a survey of American chiropractors. J Manipulative Physiol Ther. 1994 Dec;17(9):584-90.

8. Guillaume Goncalves, Demortier M, Leboeuf-Yde C, Wedderkopp N. Chiropractic conservatism and the ability to determine contra-indications, non-indications, and indications to chiropractic care: a crosssectional survey of chiropractic students. Chiropractic \& Manual Therapies [Internet]. 2019 Dec [cited 2019 Aug 6];27(1). Available from: https://chiromt.biomedcentral.com/articles/10.1186/s12998-018-0227-6

9. Nim CG, Lauridsen HH, O’Neill S, Goncalves G, Jensen RK, Leboeuf-Yde C. Chiropractic students in Denmark and their adherence to chiropractic conservatism - A cross-sectional study: UNPUBLISHED

10. Studienævnet for Klinisk Biomekanik. SYDDANSK UNIVERSITET STUDIEORDNING FOR BACHELORUDDANNELSEN I KLINISK BIOMEKANIK [Internet]. Sundhedsvidenskabeligt Fakultet, Syddansk Universitet; 2014 [cited 2020 Mar 1]. Available from:

https://www.sdu.dk/da/uddannelse/bachelor/klinisk_biomekanik/uddannelsens_opbygning/studieordning

11. Management Consulting. Documentation and description of SurveyXact's REST-based API [Internet]. Ramboll; 2016 [cited 2020 Jul 4]. Available from: https://www.surveyxact.dk/media/1430/documentationfor-surveyxacts-rest-api.pdf

12. What to notify? [Internet]. [cited 2020 Mar 28]. Available from: http://en.nvk.dk/how-to-notify/what-to-notify

13. Beaton DE, Bombardier C, Guillemin F, Ferraz MB. Guidelines for the Process of Cross-Cultural Adaptation of Self-Report Measures: Spine. 2000 Dec;25(24):3186-91.

14. Axén I, Rosenbaum A, Eklund A, Halasz L, Jørgensen K, Lövgren PW, et al. The Nordic maintenance care program - case management of chiropractic patients with low back pain: A survey of Swedish chiropractors. Chiropractic \& Osteopathy [Internet]. 2008 Dec [cited 2019 Dec 10];16(1). Available from: https://chiromt.biomedcentral.com/articles/10.1186/1746-1340-16-6

15. Debarle M, Aigron R, Depernet L, Guillemard A, Véron T, Leboeuf-Yde C. Management of patients with low back pain: a survey of French chiropractors. Chiropr Man Therap. 2014 Mar 28;22:13. 
16. Møller LT, Hansen M, Leboeuf-Yde C. The Nordic Maintenance Care Program - An interview study on the use of maintenance care in a selected group of Danish chiropractors. Chiropractic \& Osteopathy [Internet]. 2009 Dec [cited 2020 Jan 3];17(1). Available from: https://chiromt.biomedcentral.com/articles/10.1186/1746-1340-17-5

17. Guenoun O, Debarle M, Garnesson C, Proisl S, Ray D, Leboeuf-Yde C. Case management of chiropractic patients with cervical brachialgia: A survey of French chiropractors. Chiropractic \& Manual Therapies. 2011;19(1):23.

18. Innes SI, Leboeuf-Yde C, Walker BF. Chiropractic student choices in relation to indications, non-indications and contra-indications of continued care. Chiropractic \& Manual Therapies [Internet]. 2018 Dec [cited 2019 Aug 6];26(1). Available from: https://chiromt.biomedcentral.com/articles/10.1186/s12998-017-0170-y

19. Wickham H, Averick M, Bryan J, Chang W, McGowan L, François R, et al. Welcome to the Tidyverse. Journal of Open Source Software. 2019 Nov 21;4(43):1686.

20. R Development Core Team. R: A Language and Environment for Statistical Computing [Internet]. Vienna, Austria: R Foundation for Statistical Computing; 2009. Available from: http://www.R-project.org

21. Fay MP. Two-sided Exact Tests and Matching Confidence Intervals for Discrete Data [Internet]. 2017. Available from: https://cran.r-project.org/web/packages/exactci/index.html

22. Education Position Statement - FNKS [Internet]. [cited 2020 Mar 15]. Available from: https://fnks.org/2020/01/30/education-position-statement/

23. Terwee CB, Prinsen CAC, Chiarotto A, Westerman MJ, Patrick DL, Alonso J, et al. COSMIN methodology for evaluating the content validity of patient-reported outcome measures: a Delphi study. Quality of Life Research. 2018 May;27(5):1159-70.

24. Marshall TR. The 1964 Surgeon General's Report and Americans' Beliefs about Smoking. Journal of the History of Medicine and Allied Sciences. 2015 Apr 1;70(2):250-78.

25. Tulchinsky TH, Varavikova EA. A History of Public Health. In: The New Public Health [Internet]. Elsevier; 2014 [cited 2020 Mar 20]. p. 1-42. Available from:

https://linkinghub.elsevier.com/retrieve/pii/B978012415766800001X

\section{Figures}




\section{CP3 Upper motor lesion}

Development of upper motor lesion in the underextremity

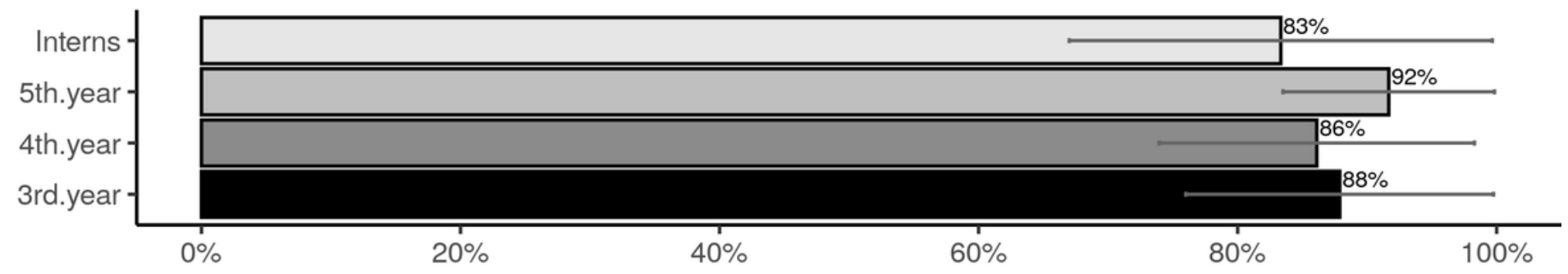

\section{LBP3 Pain aggravation}

No improvement and worsening of pain after six consultations

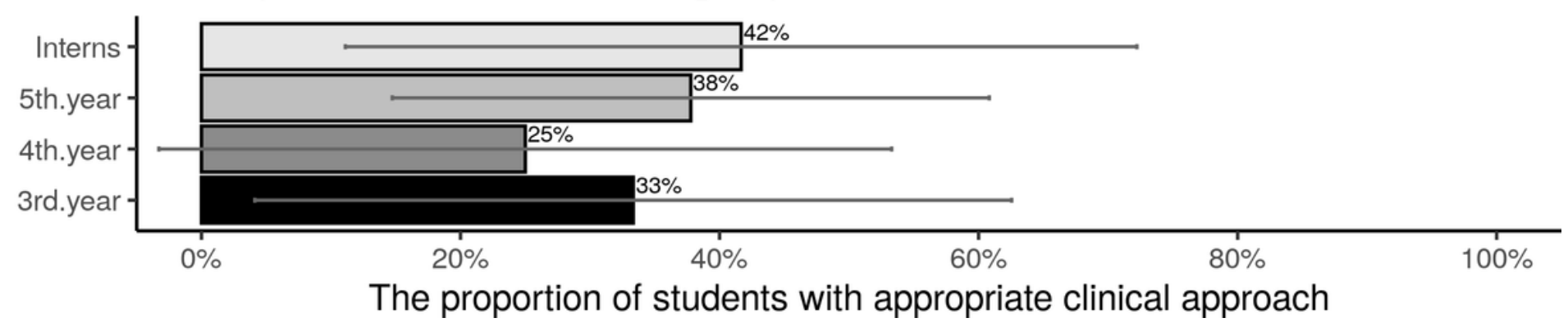

Figure 1

Proportions and $95 \%$ confidence intervals of chiropractic students able to select contra-indications for chiropractic treatment 


\section{LBP4 Depression}

No improvement, possible underlying depression

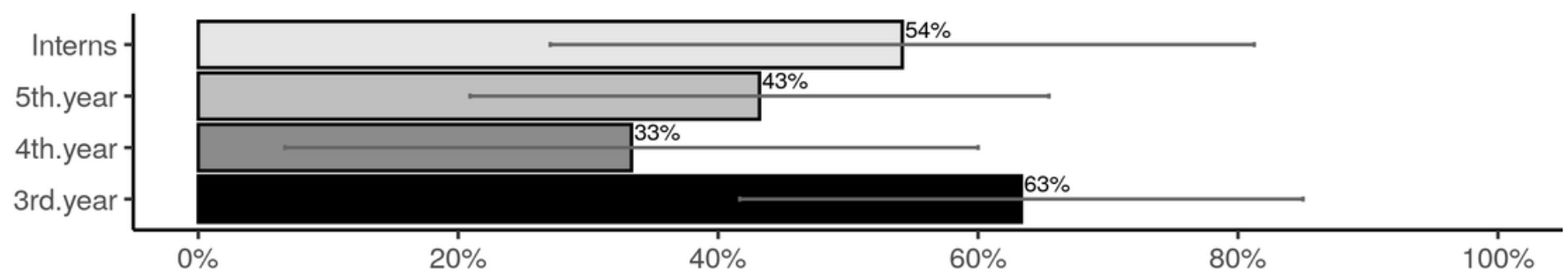

\section{LBP1 Mechanical back pain}

Complete recovery, no history of $L B P$

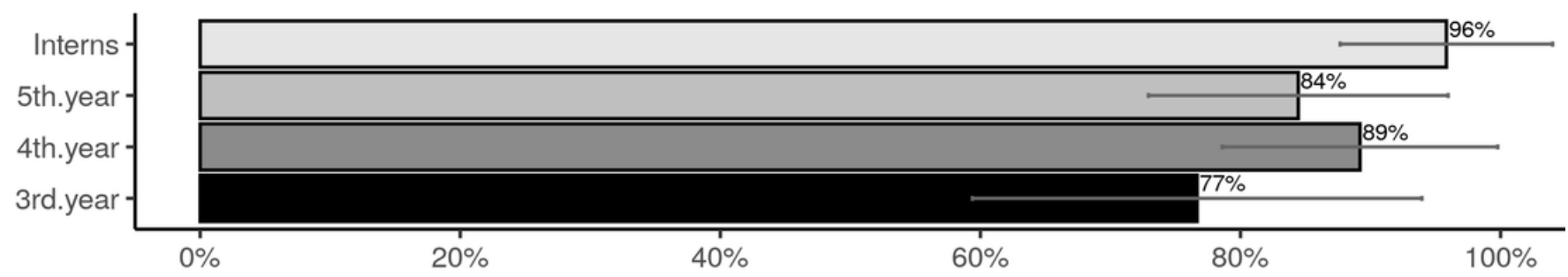

\section{PED1 Primary prevention of back disorders}

Prevention of back pain on an asymptomatic child

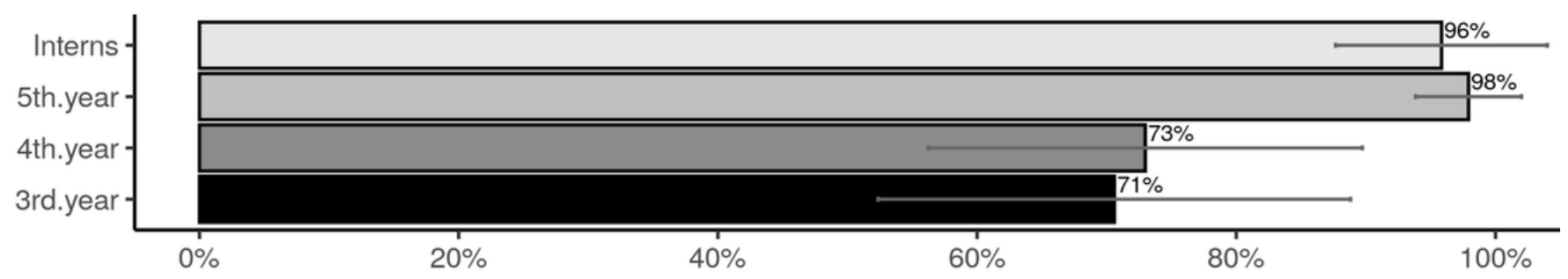

\section{PED2 Primary prevention of diseases}

Prevention of general diseases on an asymptomatic child

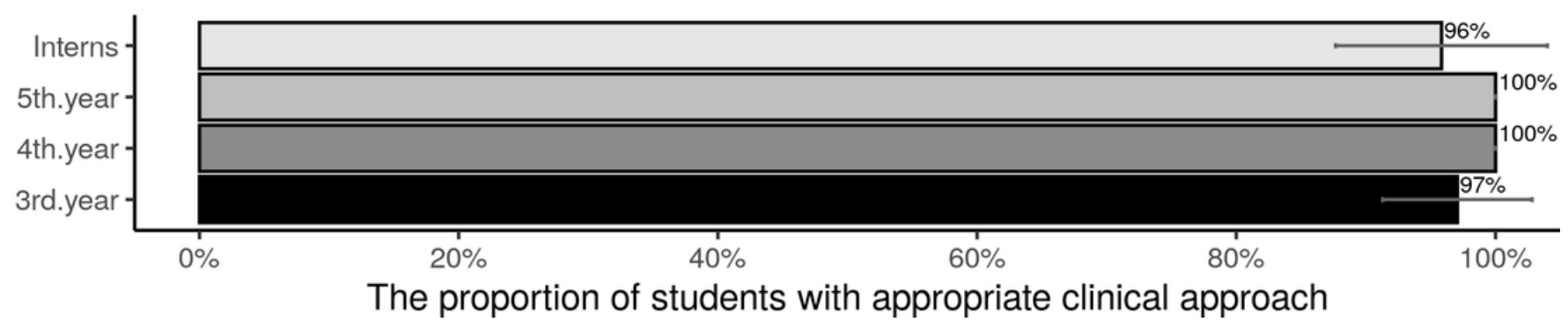

Figure 2

Proportion and $95 \%$ confidence intervals of chiropractic students able to select non-indications for chiropractic treatment 


\section{CP1 Mechanical neck pain}

\section{Local neck pain}

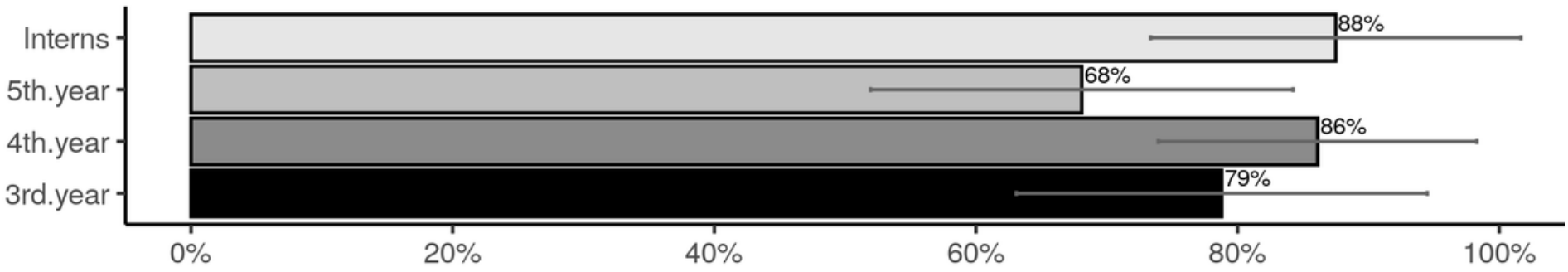

\section{CP2 Mechanical neck pain}

Local neck pain, radiation to the trapezius

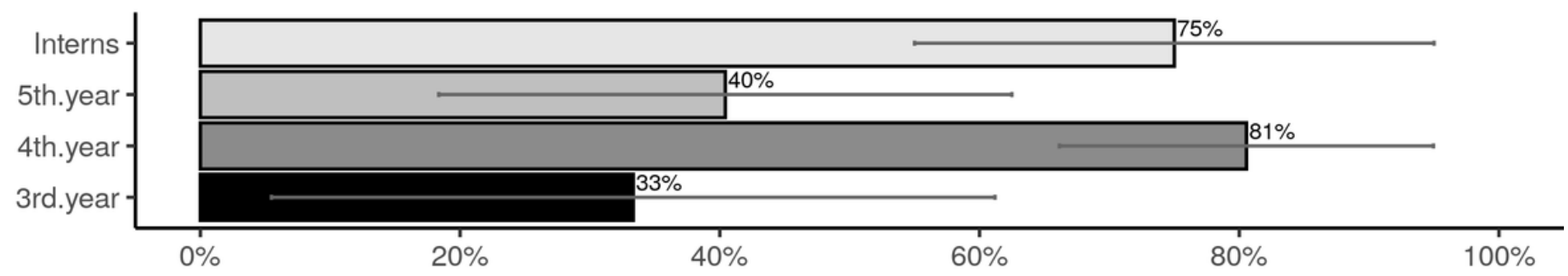

\section{LBP2 Recurrent low back pain}

Episodic LBP over 12 months, complete recovery

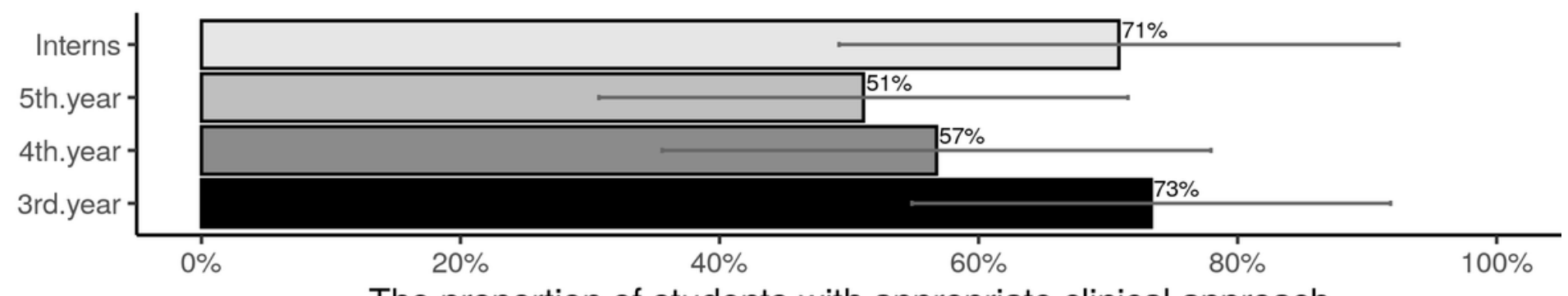

The proportion of students with appropriate clinical approach

Figure 3

Proportion and $95 \%$ confidence intervals of chiropractic students able to select indications for chiropractic treatment

\section{Supplementary Files}

This is a list of supplementary files associated with this preprint. Click to download.

- Supplementary.file.1.docx

- Supplementary.file.3.docx

- Supplementary.file.2.docx 